\title{
Turismo rural no município da Lapa - PR: perspectivas e dilemas
}

\author{
Joyce Meri Sera MARQUES
}

Dissertação de Mestrado: Curso de Mestrado em Geografia - UFPR

Data da defesa: 19 set. 2003

Banca:

Júlio César Suzuki (orientador)

Claudete de Castro Silva Vitte

Luís Lopes Diniz Filho

\section{RESUMO}

Análise das perspectivas e dilemas pelas quais passa a consolidação do turismo rural no Município da Lapa - PR, no período de 2001 a 2002, sob o enfoque crítico, com o propósito de reconhecimento dos aspectos econômicos e sociais que envolvem a atividade do turismo rural, bem como todas as pessoas envolvidas. Discorre sobre aspectos gerais quanto à economia local, bem como a distribuição populacional nas atividades econômicas desenvolvidas. Salienta as evoluções tecnológicas pelas quais as propriedades envolvidas passaram a fim de atender melhor seus visitantes e a demanda crescente. Para tal análise foram feitas entrevistas com os proprietários em dois momentos, um em 2001, quando se contavam apenas quatro propriedades, e outra em 2002, quando se contavam nove proprietários. As aspirações, dilemas e projetos futuros foram destacados de modo a estabelecer o turismo rural como uma alternativa de atividade para estas propriedades.

Palavras-chave:

Lapa, turismo rural, meio rural. 